\title{
Angel Financing and the Performance of High-Tech Start-Ups
}

\author{
by Annalisa Croce, Massimiliano Guerini, and Elisa Ughetto
}

In this paper, we investigate what drives the performance of high-tech start-ups receiving angel financing, while taking a closer look at the capabilities (i.e., experience) and investment behavior of business angels (BAs). We exploit a new data set (extracted from Crunchbase), which consists of 1,933 high-tech start-ups that received at least one financing round from a BA. The results indicate that the experience of BAs in early stage investments is positively associated with additional receipt of follow-on rounds of financing and sequential capital injections from venture capitalists (VCs). Later-stage experience is positively associated with the start-up's success (i.e., probability to be listed or acquired), but reduces the need for new VCs to invest in the start-up. Furthermore, we find consistent evidence that start-ups that combine BA and VC financing experience higher levels of funding amounts, additional VC financing, and an improved likelihood of success. Finally, we find that the co-localization of BA investors and start-ups in the same area facilitates the attraction of VCfinancing.

\section{Introduction}

Informal capital is generally considered as a primary source of external financing for startups, given the difficulties that these firms typically face in obtaining finance from traditional sources such as banks or stock markets (Carpenter and Petersen 2002; Hall 2002). The market for informal capital ${ }^{1}$ is populated by high net worth individuals with considerable business experience, commonly known as business angels (BAs), who invest a portion of their wealth in high-risk, high-return start-ups (Cove- ney and Moore 1998; Lindsay 2004). BAs target ventures whose capital requirements fall below what venture capitalists (VCs) would require (Goldfarb et al. 2013; OECD, 2011; Shane 2012).

Several works have attested the importance of angel financing in various countries where the so-called "equity gap" is said to be most significant (e.g., Freear, Sohl, and Wetzel 1995; Landström 1993; Mason and Harrison 1994; Shane 2012). BAs have been reported to contribute in approximately 20 times the number of entrepreneurial ventures in the U.S. market

Annalisa Croce is associate professor in the Department of Management, Economics and Industrial Engineering at Politecnico di Milano.

Massimiliano Guerini is assistant professor in the Department of Management, Economics and Industrial Engineering at Politecnico di Milano.

Elisa Ughetto is assistant professor in the Department of Management and Production Engineering at Politecnico di Torino.

Address correspondence to: Elisa Ughetto, Politecnico di Torino Corso Duca degli Abruzzi 24, 10129 Torino, Italy. E-mail: elisa.ughetto@polito.it.

${ }^{1}$ According to Shane (2012), funding from family, friends and fools (FFFs) should not be considered part of the informal capital market. However, it is worth noting that FFFs far outweighs funding from BAs and VCs as reported by the Angel Capital Education Foundation (2010). Start-up funding from VCs and angel investors totals approximately $\$ 20.8$ billion annually, while FFFs contribute nearly three times the amount of capital, with approximately $\$ 60$ billion. An astonishing 87 percent of all funding of private companies in the United States comes from FFFs as opposed to other means (Angel Capital Education Foundation, 2010).

This is the peer reviewed version of the following article: "Angel financing and the performance of high-tech start-ups" (Journal of Small Business Management 2018, 56:2, 208-228), which has been published in final form at http://dx.doi.org/10.1111\% 2Fjsbm.12250. This article may be used for non-commercial purposes in accordance with Wiley Terms and Conditions for Use of Self-Archived Versions 
compared to formal VCs (Wiltbank et al. 2009). The total BA market has been recently estimated to be approximately the same size than the VC market, being the U.S. (European) VC market at $\$ 18.3$ billion ( $\$ 5.3$ billion) and the U.S. (European) BA market at $\$ 17.7$ billion ( $\$ 5.6$ billion) (OECD 2011). ${ }^{2}$

Despite its importance, angel financing is still a neglected segment of entrepreneurial finance and has received much less attention than VC financing so far (Gompers and Lerner 2001; Hellmann et al. 2013). Prior research has been devoted to the description of the characteristics of BAs, of the modes and rationales behind angel investing and of the potential differences between BAs and VCs in terms of objectives, funding sources, time horizons, and screening procedures. Most works are descriptive in nature or based on surveys of limited size. BAs have been described as wealthy individuals, often former entrepreneurs themselves, who place their own money into early stage entrepreneurial ventures, acting alone or through semiformal networks (Freear and Wetzel 1990; Wiltbank et al. 2009). In contrast to VCs, BAs are patient and long-term investors, since they are not constrained to exit their investments within a limited and predefined period. Being their own principals, they are also facing less pressures for reputation building than VCs and are more likely to engage in ex post monitoring activities by building closer partnerships with the entrepreneur (Bammens and Collewaert 2014; Bonnet and Wirtz 2012; De Clercq et al. 2006; Fairchild 2011; Madill, Haines, and Riding 2005; Van Osnabrugge 2000).

Considerably less is known about the relationship between BA characteristics, attitudes, behaviors, and venture success (Wiltbank 2005). A few studies have focused on single institutional settings to assess the actual impact of BA financing on the performance and premoney evaluation of invested ventures (Collewaert and Manigart, 2016; Bruton et al. 2010;
Chahine, Filatotchev, and Wright 2007; Johnson and Sohl 2012; Kerr, Lerner, and Schoar 2014; Werth and Boeert 2013). Kerr, Lerner, and Schoar (2014) collect data at the deal level from two well-known angel investment groups in the United States (Tech Coast Angels and CommonAngels) during the 2001-2006 period and compare firms that received angel funding to those that pitched to angel financing but did not. Overall, they find that financing by angel groups is associated with improved likelihood of survival for four or more years, higher levels of employment, and a higher likelihood to undergo a successful exit (initial public offering [IPO] or acquisition), while mixed results are obtained in terms of superior follow-on financing. Werth and Boeert (2013), using data from Crunchbase on 1,746 technology BA-backed start-ups, find that firms funded by better connected BAs are more likely to receive subsequent funding by VCs and are more likely to exit successfully. Bruton et al. (2010) study the effects of BA and VC investors on IPOs in the U.K. and French markets during the period 1996-2002. They find that BAs have a significant value-enhancing effect on IPO firm performance compared to VCs. Similar results are obtained in the companion paper by Chahine, Filatotchev, and Wright (2007). Johnson and Sohl (2012) analyze U.S. firms undergoing an IPO backed by VCs, Bas, and co-invested by both BAs and VCs. They show that VCs, compared to BAs, seem to be better able to exit their investments at peaks in market price. Moreover, while VC-backed IPOs have higher median operating performance than non-VCbacked IPO firms, BA-backed IPO firms do not perform better than non-BA-backed IPO firms and by some measures, perform worse. This is explained by the inability of BA investors to attract high-quality underwriters.

In this paper, we address the question of how BAs affect the performance of funded startups, which hitherto, has received inadequate

\footnotetext{
${ }^{2}$ However, this market is difficult to accurately quantify because of its informal nature (Fenn and Liang 1998; Prowse 1998). Available figures mainly refer to the U.S. market and generally suggest that BA financing dominates VC financing, both in terms of number of invested firms and of total amount of financial investment (Sohl 2005; Wiltbank 2005; Wiltbank et al. 2009). According to Crunchbase, the U.S. angel market grew at an annual rate of 33 percent between 2007 and 2013 (Hellmann and Thiele 2015). Fenn and Liang (1998) also reported that in the United States, for every one firm that raised VC, six raised a BA investment and that approximately onethird of firms that went public were funded by VCs and two-thirds by BAs. Moreover, the number of individuals who fulfil all the conditions for becoming BAs but that have never invested has been estimated to be 850,000 in Europe and 1.75 million in the United States (CVR 2003).
} 
attention from the scientific literature. We contribute to the extant literature on entrepreneurial finance in several ways. First, we are interested in investigating what drives the performance of start-ups receiving BA financing. The few extant empirical assessments have generally examined to what extent BA financing impacts upon the postinvestment performance of investee firms, without focusing on the attitudes and traits of BAs. Accordingly, we link the BA's capabilities (i.e., experience) and investment behavior (i.e., established links with VCs, co-localization of BA investors and funded start-ups in the same area, and monitoring via staged capital injections) to the interim and ultimate start-up's success. Interim success is proxied with the total amount of financing received by the start-up, the receipt of a follow-on round of financing and the ability to attract VC investors. Ultimate success implies the "cashing out" of the investment through an IPO or an acquisition. As far as we know, this is the first study that examines to what extent the capabilities and investment behavior of BAs affect different measures of a start-up's interim and ultimate success.

Second, we exploit a new and detailed data set (extracted from Crunchbase ${ }^{3}$ ) that consists of 1,933 high-tech start-ups that received at least one financing round from a BA investor. Due to the novelty and richness of the database at our disposal, we provide fresh evidence at an unparalleled level with respect to the extant studies in the field, which generally have a national focus and analyze samples of limited size. To date, literature contributions have offered insights into the effect of BA financing for one particular country, privileging United States and United Kingdom (Bruton et al. 2010; Johnson and Sohl 2012; Kerr, Lerner, and Schoar 2014; Werth and Boeert 2013). However, there is a substantial lack of evidence in other institutional frameworks, and this is even more surprising given the critical importance of BAs in many world economies. Different framework conditions are likely to affect the development of the BA market (tax regimes, entrepreneurial culture, administrative and legal constraints, efficiency and development of equity markets) and ultimately, the performance of funded ventures. In addition, due to the difficulties in identifying the population of BAs, much of the existing studies are mainly descriptive in their nature and are based on survey evidence (Bonnet and Wirtz 2012; Freear, Sohl, and Wetzel 2002). Our database allows to identify BAs with no ambiguity and to conduct a multivariate analysis in a crosscountry and cross-industry context.

The results indicate that the experience of BAs in early stage investments is positively associated with a better interim performance, in terms of both follow-on rounds of financing and sequential capital injections from VCs. These findings confirm that the provision of early stage finance provides a valuable signal to entrant investors. Later stage experience is positively associated with start-up's ultimate success, but reduces the need for new VCs to invest in the start-up. Furthermore, we find consistent evidence that start-ups that combine BA and VC financing experience higher levels of funding amounts, additional VC financing and an improved likelihood of ultimate success. Sequential investment of VCs after BA financing is also positively and significantly associated with ultimate success, a result that is consistent with much of the prior literature. Finally, we find that the co-localization of BA investors and investees in the same area facilitates the attraction of VC financing.

The remainder of the paper is organized as follows. The hypotheses development section puts forward some testable hypotheses in the context of the prior research. The data section introduces the data and provides some relevant descriptive statistics. The empirical analyses section describes the main variables used and discusses the results of the empirical analysis. The conclusion section concludes and summarizes the paper.

\section{Hypotheses Development}

In this section, we gain insight into the relationship between BA financing and the performance of funded high-tech start-ups. We identify two main areas of investigation that might affect the performance of BA-backed start-ups: the BA capabilities (in terms of BAs' investment experience in both seed/early stages and in later development stages) and the BA investment behavior. When investigating the investment behavior of BAs, we distinguish between: colocalization of BA investors and funded startups in the same area, established links with

\footnotetext{
${ }^{3} \mathrm{http}: / /$ www.crunchbase.com.
} 


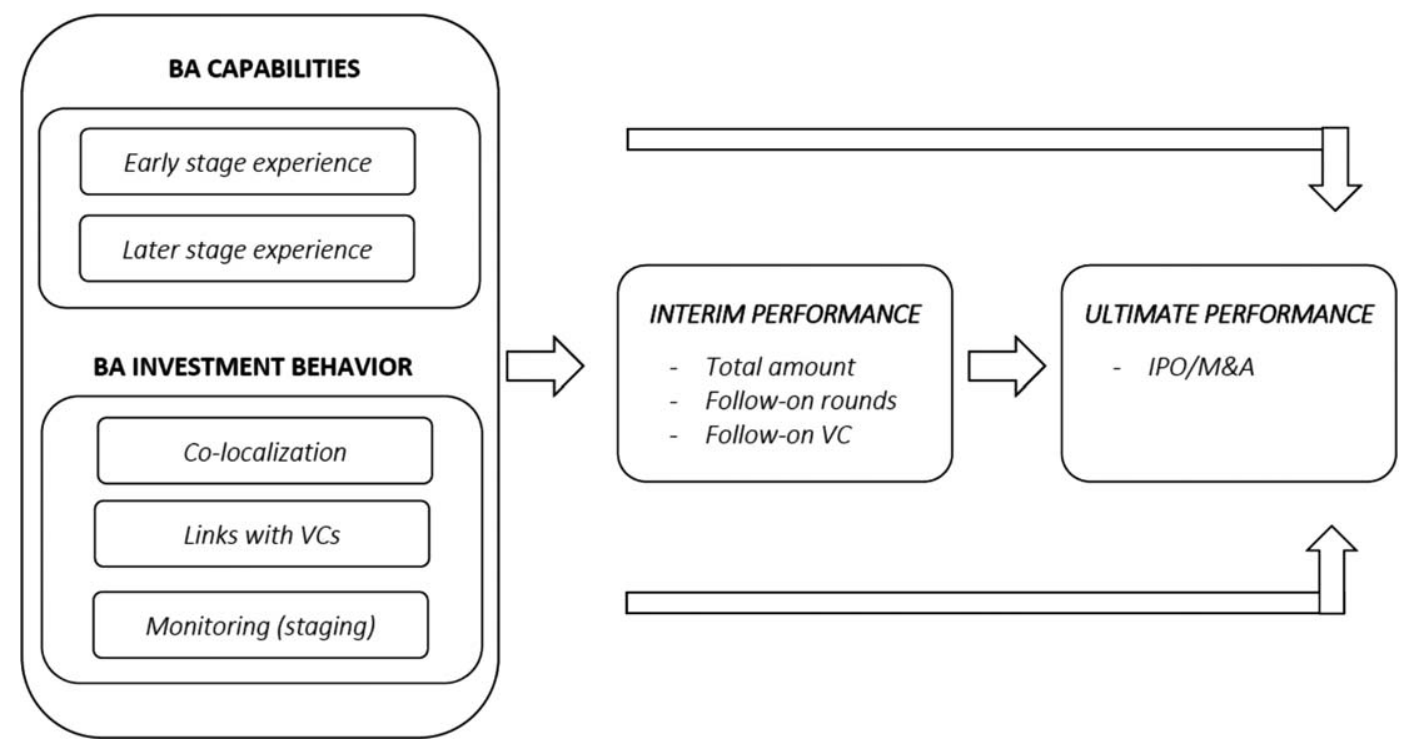

Note: The figure illustrates how the BA capabilities (in terms of BA's investment experience in both seed/early stages and in later development stages) and the BA investment behavior (in terms of co-localization of BA investors and funded start-ups in the same area, established links with VCs, either in the form of co-investments or sequential investments and BA monitoring via staging) are likely to affect interim (total amount of funding received, probability to receive a follow-on round and probability to be subsequently invested by a VC) and ultimate performance (probability of a successful exit through IPO/M\&A).

VCs, either in the form of co-investments or sequential investments (i.e., VCs after BAs), and BA monitoring via staging. The identified factors are likely to affect two types of outcomes: interim and ultimate performance. We identify the following interim outcomes: total amount of financing raised by the start-up, receipt of a follow-on round of financing, and capital injection by a VC investor. We refer to the probability of IPO/acquisition as a proxy of the startup's ultimate performance. Figure 1 provides a simple schematic structure that summarizes the main elements (BA capabilities, BA investment behavior, interim and ultimate performance) upon which research hypotheses will be built.

An important factor for the success of a funded start-up is the proper management of the investment process, whereby the entrepreneurial experience and the strategy adopted are decisive factors as the provision of capital. In addition to their financial role in the start-up's development (Mason 2006), BAs influence the strategies of the funded start-ups by formally participating on the firm's board of directors and by providing knowledge and expertise (Wiltbank et al. 2009). Typically, BAs have substantial entrepreneurial experience of their own and therefore represent a sounding reference for entrepreneurs (Amis and Stevenson 2001). BAs are predominantly actual or former entrepreneurs (Coveney and Moore 1998; Lindsay 2004; Morrissette 2007): they can have gained professional experience in the foundation of a company and have contributed to its growth and development. BAs generally prefer to invest in deals referring to an industry or a market for which they have good knowledge (Van Osnabrugge 2000). In general, past entrepreneurial experience allows BAs to be skilled in discerning the potential of investment opportunities and eventually to be capable of managing the complete investment to exit. 
VCs have a preference for entering businesses that have raised an initial round financing from BAs with a sound experience in early stage investments, because this can provide significant value to the company growth. Indeed, Freear and Wetzel (1990) have demonstrated the existence of a complementarity between BAs and VCs in terms of stage of business development, with BA investors dominant at seed and start-up stages. BAs with an extensive experience in the provision of seed and early stage finance provide a supply of good-quality prescreening investment opportunities to VCs. Therefore, BA early stage experience is assumed to play a certification and signaling role toward VCs willing to invest in deals originated by BAs. However, VCs no longer need BAs in the later stages of development. Accordingly, potentially new entrant VCs would not perceive the need to invest in the start-up when backed by a BA with an experience in later stages. This double attitude of VCs, which is likely to produce both friendship and rivalry effects, has been described in Hellmann and Thiele (2015) and Hellmann, Schure, and Vo (2013). ${ }^{4}$ Given these premises, we expect that BAs' past experience in early stage investments is likely to be associated with a better interim performance and to be especially valued by entrant VCs. Instead, BA experience in later stage investments should reduce the need for new VCs to invest in the start-up. More specifically, BA experience in later stage investments is supposed to positively influence the start-up's ultimate success, while it should decrease the chances of start-ups of obtaining subsequent VC financing.

This line of arguments leads to the following testable hypotheses:

\section{H1a: The experience of BAs in early stage invest- ments is positively associated with the attrac- tion of VCfinancing.}

H1b: The experience of BAs in later stage investments is negatively associated with the attraction of VC financing.
As to the BA investment behavior, we first focus on co-localization in terms of BAs' geographical proximity to funded start-ups. Much of earlier descriptive works on BAs have evidenced that BA investors usually invest in their local economies (Sohl 1999). It is plausible that the co-localization of $\mathrm{BA}$ investors and investees in the same area is giving the BA a comparative advantage in dealing with asymmetric information and agency problems that might arise when the strategic objectives of investors diverge from those of the entrepreneurs. The cost and efficacy of providing oversight are sensitive to the distance between the BA investor and the firm in which he/she invests. If geographical proximity facilitates relational monitoring, then agency problems that might negatively affect firms' performances will be reduced. In addition, geographical proximity facilitates deploying liaisons and learning attitudes. Following this view, we advance the hypothesis that geographically localized BA investments are likely to be associated with a better intermediate and ultimate performance of funded start-ups. We therefore posit $\mathrm{H} 2$.

\section{H2: The co-localization of BA investors and investees in the same state is positively associ- ated with a better interim and ultimate per- formance of BA-backed start-ups.}

BA-backed start-ups can receive VC financing in two forms: as a co-investment with the BA or as a sequential investment in subsequent rounds of financing. Madill, Haines, and Riding (2005) document that a high proportion (57 percent) of BA-financed technology firms in Canada received both $\mathrm{BA}$ and $\mathrm{VC}$ financing. More recently, Johnson and Sohl (2012) find that only a small proportion (around 8 percent) of IPO firms see some interactions between BA and VC investors. In a similar vein, Hellmann, Schure, and Vo (2013) suggest that syndicated BA-VC investments are somewhat rare, representing only 7 percent of all financing rounds in their sample. In terms of typology of VC intervention,

\footnotetext{
${ }^{4}$ Hellmann et al. (2013) suggest dynamic substitutes patterns between BAs and VCs, which constitute alternative investment opportunities that do not mix well together. They find that deals that originally raised BA capital are less likely to then obtain VC funding and, in case of funding, raise lower amounts. The effect is more pronounced for single-company BAs than for multiple-company BAs, or for those that invest together through an angel fund. Hellmann and Thiele (2015) develop a theoretical model of how BAs and VCs interact. VCs and BAs are "friends" because they rely upon each other's investments, but they are also "foes" because VCs no longer need the angels when later stages are reached.
} 
Johnson and Sohl (2012) find that BAs and VCs invest sequentially 45 percent of the time and co-invest 55 percent of the time. In general, sequential investment has been largely documented in the United States (Freear and Wetzel 1990; Freear, Sohl, and Wetzel 1995), while less evidence has been found in United Kingdom (Mason and Harrison 1994). There is also extensive anecdotal evidence that BAs invest alongside VC funds in United States, while coinvestment is relatively uncommon in United Kingdom (Harrison and Mason, 2000).

Co-investment and sequential investing are usually motivated by the gains that the complementarity between BAs and VCs allows. Harrison and Mason (2000) explore the nature and extent of complementarities between VC and BA investors in United Kingdom, based on data collected from a survey of BAs and managers of institutional VC firms. The authors distinguish various forms of complementary relationships, notably deal referral, the provision of funds (by BAs to VC funds), co-investment and sequential investment. The study confirms the presence of a beneficial effect for invested ventures when BAs and VCs have complementary relationships.

The existence of complementarities between BAs and VCs serves the goals of both individual BAs and VCs. Several reasons can be foreseen from both the $\mathrm{BA}$ and $\mathrm{VC}$ perspectives. BA investors usually have limited resources and typically need VCs to provide a growth option for their companies (Hellmann and Thiele 2015) and an exit route to realize profitable returns. Follow-on finance by a VC (or co-investment with a VC) is often the discriminant factor that allows a firm to grow to the point that an IPO is feasible or a sale is attractive to potential acquirers. Some works document that BAs take on active roles in the firms in which they invest by providing business experience to the often unique technical knowledge of entrepreneurs (Madill, Haines, and Riding 2005). However, BAs are typically less able to provide value added services compared to VCs (Chemmanur and Chen 2014). The hands-on involvement of a VC investor is likely to improve the growth prospects of the start-ups more significantly, better qualifying the firms for commercial success. From the VC perspective, VCs take advantage of the technology and entrepreneurial experience of the BAs to identifying growth opportunities and to assisting the due diligence process. The role of BAs as prescreeners is particularly relevant for sequential VC investing. In that case BAs play a validation role of the startup's quality, thus reducing the information opacity that might otherwise inhibit VC investment (Madill, Haines, and Riding 2005). VCs also benefit from the postinvestment relationship of the BA with the portfolio firms.

The alleviation of agency problems is a relevant concern for both BAs and VCs. However, the mechanisms adopted by the two parties to address agency risk are different (Bruton et al. 2010; Van Osnabrugge 2000): while VCs employ more formal contractual and screening mechanisms to monitor investees (Lerner 1994), BAs tend to rely primarily on relational governance (Ehrlich et al. 1994). Relational governance is built by developing close partnerships with the entrepreneur, in which trust likely plays a dominant role (De Clercq et al. 2006; Fairchild 2011). The adoption of different control mechanisms reflects a different orientation in the timing of risk management that has to be attributed to the institutional nature of the two types of investors. VCs face a strong pressure from limited partners to maximize short-term financial returns and are incentivized to quickly build up a reputation in order to raise follow-on funds. As a consequence, they want to signal to fund providers that they are able to control agency risk ex-ante, through appropriate screening procedures and contracts (Bruton et al. 2010). BAs do not have to signal their skills to any external investor because they are using their own money (Johnson and Sohl 2012). They are therefore more patient and committed to the long-term development of the venture (Madill, Haines, and Riding 2005), thus relying on ex-post mechanisms of control of agency risk through active monitoring and closer relationships (Bruton et al. 2010; Van Osnabrugge 2000). Combining BAs and VCs allows to take advantage of the respective control mechanisms.

While a strong case can be made for arguing that the existence of complementarities between BAs and VCs will benefit both parties and, in turn, generates superior venture performances, the empirical literature examining the effects of the interactions between VCs and BAs is still underdeveloped. To the best of our knowledge the only two papers addressing the issue from an empirical point of view are Goldfarb et al. (2013) and Hellmann, Schure, and Vo (2013). Goldfarb et al. (2013) study the role of BA and VC financing using data from the now defunct law firm Brobeck, Phleger and Harrison. They find that when larger investments are needed, 
BA financing is insufficient and VC participation is generally necessary. Among larger deals those financed by VCs alone experience more successful exits than those in which VC and BAs invest in the same round, while the same is not found for smaller deals. Hellmann, Schure, and Vo (2013), using a data set of start-ups in British Columbia (Canada), find that the co-investments between BA and VC investors are associated with fewer exits, while start-ups backed by VCs only appear to achieve better outcomes in terms of exits, revenue and employment growth.

Consistent with these predictions we formulate our research hypotheses as follows:

\section{H3: The co-investment between BAs and VCs} is positively associated with a better interim and ultimate performance of BA-backed startups.

\section{H4: The sequential investment of VCs is positively associated with a better ultimate performance of BA-backed start-ups.}

Many of the strategies implemented by BAs are shaped by the need to provide monitoring and to limit the opportunistic behavior that investee firms can engender (Admati and Pfleiderer 1994). Another instrument that is adopted to mitigate the agency and information problems that typically accompany early stage investments is staging. Staging consists in the stepwise disbursement of capital from an investor to a venture, based on whether the venture meets certain performance thresholds (Dai 2011; Tian 2011). An extensive theoretical literature has discussed the causes and consequences of staging referring to VC investors. The use of staging by BAs as a monitoring tool has received, to our knowledge, no attention so far. As modeled in much theoretical works, stage financing represents a way to reduce agency problems associated with hold-up, moral hazard and information asymmetry (Neher 1999; Wang and Zhou 2004). Staged capital infusions represent a powerful mechanism also to limit the problem of the inefficient continuation by entrepreneurs of projects that would be better to be abandoned (Admati and Pfleiderer 1994) and allows investors to learn about the quality of the entrepreneurial venture over time (Bergemann and Hege 1998).

Given the alleviation of agency problems and the learning dynamics associated with staging, it might be argued that the use of staging by BA investors leads to better start-up performances. However, it has also been suggested that staging could induce entrepreneurs to "window dress" in order to secure the next round of financing, eventually to the detriment of long-run value creation (Sahlman 1988). From an empirical point of view, the literature examining the consequences of staging on entrepreneurial firms' performance is limited and focuses exclusively on VC. In general, the few empirical papers examining the consequences of staging find a positive effect on venture performance. Tian (2011) finds that VC staging positively affects the venture's propensity to go public, its operating performance in the IPO year, and post-IPO survival rate, but only if the firm is located far away from the VC investor. Dai (2011) looks at the consequences of staging in the setting of private investments in public equities. The author finds that staging helps issuers to reduce financing costs and to improve long-run stock performance.

Given this background, we postulate the hypothesis $\mathrm{H} 5$ :

\section{H5: The use of stage financing in BA-backed deals is positively associated with a better ulti- mate performance of BA-backed start-ups.}

\section{Data}

\section{Source of Data}

The main data source for this study is CrunchBase, a free online directory of technology companies, people, and investors mostly based on the U.S. market. ${ }^{5}$ Professionals in the technology community can add information to the database, which are reviewed by the data set managing team before being made available online. A key strength of the data set is that it contains detailed information on individuals that invested in start-up companies, thus making it well suited for a research on BA finance. Coverage of BA activity has been improved recently, as in 2013 Crunchbase entered into a

\footnotetext{
${ }^{5}$ CrunchBase is operated by TechCrunch, one of the most influential technology blogs in the United States (http://techcrunch.com). The data set is quite new and it shows a good potential for research purposes. The data set can be downloaded at http://info.crunchbase.com/about/crunchbase-data-exports.
} 
Table 1

\section{Distribution of the Sample (n. Rounds, n. Start-Ups, Amount), by Investment Year}

\begin{tabular}{lccc}
$\begin{array}{l}\text { Investment } \\
\text { Year }\end{array}$ & $\begin{array}{c}\boldsymbol{N} \text { of Financing } \\
\text { Rounds }\end{array}$ & $\begin{array}{c}\text { N. of Start-Ups Receiving } \\
\text { the First Financing Round }\end{array}$ & $\begin{array}{c}\text { Total Amount } \\
\text { (millions \$) }\end{array}$ \\
\hline Before 2007 & 164 & 128 & 519 \\
2007 & 180 & 128 & 578 \\
2008 & 243 & 165 & 644 \\
2009 & 261 & 180 & 545 \\
2010 & 408 & 278 & 920 \\
2011 & 702 & 461 & 3,230 \\
2012 & 917 & 593 & 2,162 \\
2013 & 409 & 0 & 2,673 \\
2014 & 51 & 0 & 949 \\
Total & 3,335 & 1,933 & 12,221 \\
& & & \\
\hline
\end{tabular}

The table illustrates the number of financing rounds, the number of start-ups receiving the first financing round, and the total amount invested across the years.

partnership with AngelList-a U.S. website for raising capital from accredited investors ${ }^{6}$ - to synchronize their data.

The data set includes updated information on technology companies reporting to have raised money, such as the year of establishment, the industrial field, the number of employees, the number of financing rounds received, the amount of money raised in each round of financing and the typology of financing received (e.g., angel, seed, series A venture funding, private equity). The database also reports information on investors, which can be broadly classified as individuals, financial organizations (e.g., VC and private equity firms) and companies (i.e., industrial firms that can be either investors or investee firms). The present analysis is based on data that was obtained from Crunchbase in March 2014.

\section{Sample Description}

As of March 4, 2014, the reference date for this study, the initial database included more than 43,720 technology companies. We restricted the analysis to the companies that reported to have received their first round of financing before 2013 , for a total of 28,547 companies. We dropped those companies with unknown information on the investor and typology of invest- ment. Then, we considered only those companies that received at least one financing round in which a BA (either an individual or a network) was present as an investor. It is worth pointing out that the investor classification provided by Crunchbase (i.e., individual, financial organization and company) does not allow to directly identifying the presence of a $\mathrm{BA}$ in the round of financing. Accordingly, in order to isolate with no ambiguity BA-backed deals we had to proceed in the following way. First, we restricted the initial sample to the companies that received at least a financing round of type "angel" or "seed," according to the Crunchbase classification. We decided to keep also the "seed" rounds as most of them occurred in the early years of the company life and involved individual investors. Second, we identified the companies that received at least an "angel" or "seed" round of financing from an individual investor. Third, we verified on the Crunchbase profiles, on the websites and on other public online sources whether a BA network was included among the financial organizations and companies that invested in the focal company. We, therefore, included in the final sample also the companies that received a "seed" or "angel" round of financing from BA networks. The final data set consists

\footnotetext{
${ }^{6}$ http://techcrunch.com/2013/07/12/crunchbase-and-angellist-have-a-partnership.
} 
of 1,933 high-tech start-ups that received at least one financing round from a BA, for a total number of 3,335 rounds of financing.

Table 1 provides a breakdown of the sample by year. The number of financing rounds

\section{Table 2}

\section{Distribution of the Sample (Com- pany-Level), by Macro- Geographical Area}

\begin{tabular}{lcc}
\hline Continent & N. Start-Ups & Percentage \\
\hline Africa & 4 & 0.2 \\
Asia & 136 & 7.0 \\
Europe & 405 & 21.0 \\
North America & 1,344 & 69.5 \\
South America & 16 & 0.8 \\
Oceania & 28 & 1.5 \\
Total & 1,933 & 100.0 \\
\end{tabular}

The table illustrates the distribution of startups across different macro-geographical areas. occurred before 2007 represents only 4.9 percent (i.e., 164/3,335) of the total number of financing rounds in the sample. This is driven by the fact that the Crunchbase coverage has increased over the years. Conversely, the low number of rounds observed in 2013 and 2014 is due to the exclusion of start-ups that received their first round of financing after 2012. Table 2 reports the distribution of the analyzed start-ups by macrogeographical areas. The largest majority of startups are located in North America (nearly 70 percent), followed by Europe (21 percent). In Europe, the United Kingdom accounts for a total of 126 start-ups, followed by Germany (51), France (48), and Spain (36). Table 3 illustrates the distribution of the sample by industry. We classify start-ups into industries by manually matching the start-up's business activity provided by Crunchbase to an industry classification based on NACE rev. 2 codes. The information and communication technology sector dominates (nearly 70 percent of start-ups), with 686 start-ups belonging to information service activities, followed by computer programming, consultancy and related activities (324) and telecommunications (217).

\section{Table 3}

\section{Distribution of the Sample (Company-Level), by Industry Sector (NACE Rev. 2 Classification)}

\begin{tabular}{llcc}
\hline $\begin{array}{l}\text { NACE } \\
\text { Section }\end{array}$ & \multicolumn{1}{c}{ NACE Description } & N. Start-Ups & Percentage \\
\hline C & Manufacturing & \\
D & Electricity, gas, steam and air & 52 & 2.7 \\
& $\quad$ conditioning supply & 10 & 0.5 \\
G & Wholesale and retail trade; repair of & 134 & 6.9 \\
& $\quad$ motor vehicles and motorcycles & & \\
H & Transportation and storage & 1 & 0.1 \\
I & Accommodation and food service activities & 22 & 1.1 \\
J & Information and communication & \\
K & Financial and insurance activities & 38 & 2.0 \\
L & Real estate activities & 13 & 0.7 \\
M & Professional, scientific and technical activities & 170 & 8.8 \\
N & Administrative and support service activities & 62 & 3.2 \\
P & Education & 42 & 2.2 \\
Q & Human health and social work activities & 40 & 2.1 \\
& Total & 1,933 & 100.0 \\
\hline
\end{tabular}

${ }^{\mathrm{a}}$ It includes the following industries (NACE divisions): Publishing activities (97 start-ups), Programming and broadcasting activities (25), Telecommunications (217), Computer programming, consultancy and related activities (324) and Information service activities (686).

The table illustrates the distribution of start-ups across different industry sectors. 


\section{Table 4}

\section{Number (percent) of Financing Rounds by Investor Type}

\begin{tabular}{lcc}
\hline $\begin{array}{l}\text { Investor } \\
\text { Type }\end{array}$ & $\begin{array}{l}N \text {. of } \\
\text { Rounds }\end{array}$ & $\begin{array}{c}\text { Percentage Out } \\
\text { of the Total } \\
N \text { of Rounds }\end{array}$ \\
\hline
\end{tabular}

$\begin{array}{lcc}\text { BA } & 2,238 & 67.1 \\ \text { VC } & 1,781 & 53.4 \\ \text { BA and VC } & 968 & 29.0 \\ \text { VC after BA } & 620 & 18.6\end{array}$

The table illustrates the number and percentage of financing rounds received by sample companies by considering the type of investors involved in the round (at least a BA, at least a $\mathrm{VC}$, syndicated rounds with both BA and VC, and rounds with at least a VC but previously backed by a BA).

Let us now turn the attention to the investment rounds. Table 4 reports a breakdown of financing rounds received by sample companies by considering the type of investors involved in the round (at least a BA, at least a VC, syndicated rounds with both $\mathrm{BA}$ and $\mathrm{VC}$, and rounds with at least a VC but previously backed by a BA). Out of 3,335 rounds, at least a BA participated in 2,238 rounds and at least a VC participated in 1,781 rounds. In 968 cases BAs and VCs co-invested (while in 1,270 rounds BAs invested alone) in the same financing round. Hence, in our sample BA-VC co-investments represent 29 percent of all the financing rounds in the sample, and 43 percent of the financing rounds in which at least a BA is present (968/ 2,238 ). Out of 1,781 rounds in which at least a $\mathrm{VC}$ was present as an investor, in 813 rounds the VC invested alone, while in 620 invested sequentially to the $\mathrm{BA}^{7}$

Table 5 reports some descriptive statistics (mean and median values) concerning the number of investors (by distinguishing BAs and
VCs) and amount of financing by round number. Both the average and the median number of BAs decrease steadily from round 1 to round 5. Conversely, the number of VCs and the amount raised increases across the rounds. These figures support the conventional wisdom that BAs invest in the early development phases of a start-up, while VC's intervention occur at later stages and is associated with higher amounts.

Finally, Table 6 reports some preliminary evidence based on descriptive statistics that link start-up's ultimate success (i.e., start-ups that went public or have been acquired) to a set of variables associated with BA capabilities (i.e., experience) and investment behavior. As to BA experience, we proxied BA experience in early and later stage rounds by considering the number of prior investments in early and later stage rounds that the BAs made before investing in the focal start-up, respectively. ${ }^{8}$ More specifically, we first calculated the (early and later stage) experience of all BAs that have invested in the focal start-up, then we considered the most experienced BA in all financing rounds. As to the BA investment behavior, we considered dummy variables that equal 1 if at least a $\mathrm{BA}$ is located in the same State (if the start-up is located in the United States) or country of the start-up (BA co-localization), if there is a VC among the investors (investing either with a BA in a given financing round or in a sequential round) and if the same BA provided multiple rounds of finance (BA staging). For each variable, Table 6 reports mean values and standard deviations considering: (1) all 1,933 start-ups in our sample; (2) only successful start-ups-that is, start-ups that had gone public or had been acquired by March 2014 (178 start-ups); and (3) unsuccessful start-ups. Finally, the last column of Table 6 reports mean differences between successful and unsuccessful start-ups.

Successful start-ups have been financed from more experienced BAs than unsuccessful startups (8.64 versus 4.70 as to early stage experience and 119.83 versus 67.85 as to later stage experience). Furthermore, successful start-ups

${ }^{7}$ In our sample the proportion of BA-backed start-ups that received VC is 56 percent $(1,086 / 1,933)$. Madill et al. (2005) find that the proportion of BA-backed firms in Canada that received both BA and VC financing is 57 percent. In Goldfarb et al.'s (2013) study on California-based firms, this proportion is 78 percent.

${ }^{8}$ Our measure of BA experience is constructed from the database itself. This is a clear limitation that we acknowledge. However, the use of prior investments as a proxy for investment experience is quite common in the entrepreneurial finance literature (see, e.g., Sørensen 2007, in the context of venture capital). 
Table 5

Investor Type and Amount by Round Number

\begin{tabular}{|c|c|c|c|c|c|c|c|}
\hline \multirow[t]{2}{*}{ Round Number } & \multirow[t]{2}{*}{$N$. } & \multicolumn{2}{|c|}{ Number of BAs } & \multicolumn{2}{|c|}{ Number of VCs } & \multicolumn{2}{|c|}{$\underset{(\text { millions } \$)}{\text { Amount }}$} \\
\hline & & Mean & Median & Mean & Median & Mean & Median \\
\hline First Round & 1,933 & 2.0 & 1 & 0.8 & 0 & 0.7 & 0.3 \\
\hline Second Round & 893 & 1.4 & 0 & 1.6 & 1 & 2.5 & 1.0 \\
\hline Third Round & 340 & 0.8 & 0 & 2.2 & 2 & 6.0 & 3.0 \\
\hline Fourth Round & 110 & 0.5 & 0 & 2.5 & 2 & 19.8 & 6.0 \\
\hline Fifth and Subsequent Rounds & 59 & 0.1 & 0 & 3.1 & 3 & 73.1 & 14.0 \\
\hline All Rounds & 3,335 & 1.7 & 1 & 1.2 & 1 & 3.7 & 0.5 \\
\hline
\end{tabular}

The table reports descriptive statistics (mean and median values) concerning the number of investors (BAs and VCs) and amount of financing by round number.

\section{Table 6 \\ Descriptive Statistics on Start-Ups' Ultimate Success and BA Characteristics}

\begin{tabular}{|c|c|c|c|c|c|c|c|}
\hline & \multicolumn{2}{|c|}{$\begin{array}{l}\text { All Start-Ups } \\
(N=1,933)\end{array}$} & \multicolumn{2}{|c|}{$\begin{array}{c}\text { Successful } \\
\text { Start-Ups } \\
(N=178)\end{array}$} & \multicolumn{2}{|c|}{$\begin{array}{c}\text { Unsuccessful } \\
\text { Start-Ups } \\
(N=1,755)\end{array}$} & \multirow[t]{2}{*}{ Difference } \\
\hline & Mean & Std. Dev. & Mean & Std. Dev. & Mean & Std. Dev. & \\
\hline $\begin{array}{l}\text { BA Experience in Early } \\
\text { Stage Investments }\end{array}$ & 5.05 & 6.74 & 8.46 & 7.79 & 4.70 & 6.53 & $3.76^{* * * * *}$ \\
\hline $\begin{array}{l}\text { BA Experience in Later } \\
\text { Stage Investments }\end{array}$ & 72.64 & 111.51 & 119.83 & 134.46 & 67.85 & 107.81 & $51.98^{* * * * * *}$ \\
\hline BA Co-Localization ${ }^{\mathrm{a}}$ & 0.78 & 0.42 & 0.79 & 0.41 & 0.78 & 0.42 & 0.01 \\
\hline $\begin{array}{l}\text { BA Co-Investment } \\
\text { with VC }\end{array}$ & 0.45 & 0.50 & 0.61 & 0.49 & 0.43 & 0.50 & $0.18^{* * * *}$ \\
\hline $\begin{array}{l}\text { Sequential Investment } \\
\text { of } \mathrm{VC} \text { after BA }\end{array}$ & 0.11 & 0.32 & 0.07 & 0.26 & 0.12 & 0.32 & $-0.05^{*}$ \\
\hline BA Staging & 0.14 & 0.34 & 0.08 & 0.28 & 0.14 & 0.35 & $-0.06^{* *}$ \\
\hline
\end{tabular}

${ }^{\mathrm{a}}$ Mean values are calculated on a reduced sample of 1,857 start-ups (of which 176 successful).

The Table reports descriptive statistics (mean and standard deviation) that link start-up's ultimate success (i.e., start-ups that went public or have been acquired) to a set of variables associated with BA capabilities (i.e., experience) and investment behavior.

The asterisks, ***, ***, and * indicate, respectively, significance levels of $<1$ percent, $<5$ percent, and $<10$ percent.

have received at least a $\mathrm{BA}-\mathrm{VC}$ co-investment more frequently than unsuccessful start-ups (61 percent versus 43 percent). All these differences are statistically significant at the 1 percent level. This evidence is in line with the view that BA experience and BA-VC co-investment are 
positively associated with the start-up's ultimate success. Quite surprisingly, sequential VC investment is more frequent for unsuccessful start-ups (12 percent for unsuccessful start-ups, 7 percent for successful start-ups), even though the difference is significant only at the 10 percent level. Finally, also BA staging is more frequent in unsuccessful start-ups (14 percent for unsuccessful start-ups, 8 percent for successful start-ups). In this latter case, the difference is statistically significant at the 5 percent level.

\section{Empirical Analyses}

In the empirical analysis, we run a series of econometric models to investigate the impact of certain characteristics that can be ascribed to BAs on different measures of performance. As mentioned, we consider two types of outcomes: interim and ultimate success. We identify the following interim outcomes: total amount of funding raised by the start-up, probability of receiving a follow on round of financing, and probability of receiving a sequential capital injection by a VC investor. We refer to the probability of IPO/acquisition as a proxy of a startup's ultimate success. In the following paragraphs, we first report the results concerning the ultimate performance (Table 7 ) and then the results referring to the interim performance, in terms of total amount of financing raised (Table 8), follow-on financing (Table 9) and follow-on financing from VCs (Table 10).

\section{Ultimate Performance}

We conducted an analysis using probit regressions on the probability that the start-up had gone public or had been acquired by March 2014 (for a similar approach that uses both IPOs and M\&As to denote a successful exit see, among others, Cumming and Dai 2010, 2013; Hochberg, Ljungqvist, and Lu 2007; Phalippou and Gottschalg 2009). ${ }^{9}$ The unit of analysis is therefore the company. As to BA capabilities and investment behavior, we considered the same variables described already when introducing Table 6, namely BA experience in early stage investments, $\mathrm{BA}$ experience in later stage investments, BA co- localization, BA co-investment with VC, sequential investment of $\mathrm{VC}$ after BA, and BA staging. We controlled for the average number of investors per round (and its squared term), the average amount per round, the total number of financing rounds (and its squared term) and whether the start-up is in the seed or early stage when receiving the first financing round. We also included company's industry and country dummies. Finally, we included dummies related to the year in which the start-up received the first financing round.

The results are reported in Table 7. Model 1 includes only controls, Model 2 adds variables concerning BAs capabilities (early and later stage experience). Models 3-5 add BA colocalization (Model 3), BA co-investment with $\mathrm{VC}$ and sequential investment of VC after BA (Model 4), and BA staging (Model 5) variables. Results on the regressions obtained by adding all the $\mathrm{BA}$ variables are shown in the last column (Model 6).

Results show that BA experience in later stage investments is positively associated with ultimate success. The coefficient is indeed positive and significant at the 5 percent level in both Models 2 and 6 (when including all the BA variables). We also find a positive and significant (at the 5 percent level) coefficient for the BA experience in early stage investments in Model 2. However, when including all the $\mathrm{BA}$ variables in the regression (Model 6), BA experience in early stage investments becomes less significant (at the 10 percent level). As to the BA investment behavior, we find that both the BA coinvestment with a VC and the sequential investment of a VC after a BA are significant at the 1 percent level (Models 4 and 6), in line with hypotheses H3 and H4. Conversely, the colocalization of a BA with the target companies (Model 3) and BA staging (Model 5) are not significant.

\section{Interim Performance}

In this section we present evidence based on whether the company received additional equity financing in subsequent rounds (from other BAs or VCs). Specifically, we consider as indicators

\footnotetext{
${ }^{9}$ To exclude the possibility of M\&A exits that possibly disguise unsuccessful investments sold to the management for a nominal sum (liquidation sales), we also checked the acquisition price for the sub-sample of companies for which such information was available (109 firms). The average acquisition price is $\$ 166$ million and the median acquisition price is $\$ 50$ million. The 5th percentile of the distribution of the acquisition price is $\$ 2.6$ million, while the 95 th percentile is $\$ 930$ million.
} 


\begin{tabular}{|c|c|c|c|c|c|c|}
\hline & Model 1 & Model 2 & Model 3 & Model 4 & Model 5 & Model 6 \\
\hline $\begin{array}{l}\text { Average Number of } \\
\text { Investors Per } \\
\text { Round }\end{array}$ & 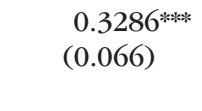 & $\begin{array}{l}0.2092^{* * * * *} \\
(0.068)\end{array}$ & 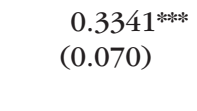 & $\begin{array}{l}0.2484^{* * * * * * *} \\
(0.068)\end{array}$ & 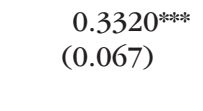 & $\begin{array}{l}0.1573^{\text {*** }} \\
(0.072)\end{array}$ \\
\hline $\begin{array}{l}\text { Average Number of } \\
\text { Investors Per } \\
\text { Round (Squared) }\end{array}$ & $\begin{array}{l}-0.0155^{\text {*** }} \\
(0.007)\end{array}$ & $\begin{array}{c}-0.0103^{*} \\
(0.006)\end{array}$ & $\begin{array}{l}-0.0157^{* *} \\
(0.007)\end{array}$ & $\begin{array}{l}-0.0110^{*} \\
(0.006)\end{array}$ & $\begin{array}{l}-0.0157^{* * *} \\
(0.007)\end{array}$ & $\begin{array}{c}-0.0073 \\
(0.006)\end{array}$ \\
\hline $\begin{array}{l}\text { Average Amount } \\
\text { Per Round }\end{array}$ & $\begin{array}{l}-0.0170^{* * *} \\
(0.008)\end{array}$ & $\begin{array}{c}-0.0139 \\
(0.008)\end{array}$ & $\begin{array}{c}-0.0139 \\
(0.008)\end{array}$ & $\begin{array}{l}-0.0214^{* * *} \\
(0.008)\end{array}$ & $\begin{array}{l}-0.0166^{* *} \\
(0.008)\end{array}$ & $\begin{array}{l}-0.0146^{*} \\
(0.009)\end{array}$ \\
\hline $\begin{array}{l}\text { Total Number of } \\
\text { Financing Rounds }\end{array}$ & $\begin{array}{l}-0.2113^{* * *} \\
(0.091)\end{array}$ & $\begin{array}{l}-0.2919^{* * * * *} \\
(0.092)\end{array}$ & $\begin{array}{l}-0.2127^{* * * *} \\
(0.092)\end{array}$ & $\begin{array}{l}-0.3534^{* * * * * *} \\
(0.095)\end{array}$ & $\begin{array}{c}-0.1854^{*} \\
(0.095)\end{array}$ & $\begin{array}{l}-0.4230^{* * * * *} \\
(0.102)\end{array}$ \\
\hline $\begin{array}{l}\text { Total Number of } \\
\text { Financing Rounds } \\
\text { (Squared) }\end{array}$ & $\begin{array}{r}0.0167 \\
(0.014)\end{array}$ & $\begin{array}{c}0.0191 \\
(0.013)\end{array}$ & $\begin{array}{c}0.0164 \\
(0.014)\end{array}$ & $\begin{array}{l}0.0283^{* *} \\
(0.013)\end{array}$ & $\begin{array}{c}0.0154 \\
(0.014)\end{array}$ & $\begin{array}{l}0.0294^{* * *} \\
(0.013)\end{array}$ \\
\hline $\begin{array}{l}\text { Company in the } \\
\text { Seed Stage at First } \\
\text { Financing Round }\end{array}$ & $\begin{array}{l}0.0113 \\
(0.145)\end{array}$ & $\begin{array}{r}0.0225 \\
(0.146)\end{array}$ & $\begin{array}{r}-0.0209 \\
(0.147)\end{array}$ & $\begin{array}{c}0.0811 \\
(0.149)\end{array}$ & $\begin{array}{c}0.0144 \\
(0.146)\end{array}$ & $\begin{array}{c}0.0526 \\
(0.150)\end{array}$ \\
\hline $\begin{array}{l}\text { Company in the } \\
\text { Early Stage at } \\
\text { First Financing } \\
\text { Round }\end{array}$ & $\begin{array}{l}0.1253 \\
(0.146)\end{array}$ & $\begin{array}{c}0.1534 \\
(0.147)\end{array}$ & $\begin{array}{c}0.0821 \\
(0.147)\end{array}$ & $\begin{array}{r}0.1621 \\
(0.149)\end{array}$ & $\begin{array}{l}0.1293 \\
(0.146)\end{array}$ & $\begin{array}{r}0.1467 \\
(0.150)\end{array}$ \\
\hline $\begin{array}{l}\text { BA Experience in } \\
\text { Early Stage } \\
\text { Investments }\end{array}$ & & $\begin{array}{l}0.0184^{* * *} \\
(0.009)\end{array}$ & & & & $\begin{array}{l}0.0151^{*} \\
(0.009)\end{array}$ \\
\hline $\begin{array}{l}\text { BA Experience in } \\
\text { Later Stage } \\
\text { Investments }\end{array}$ & & $\begin{array}{l}0.0013^{* * *} \\
(0.001)\end{array}$ & & & & $\begin{array}{l}0.0013^{* *} \\
(0.001)\end{array}$ \\
\hline BA Co-Localization & & & $\begin{array}{c}-0.0671 \\
(0.112)\end{array}$ & & & $\begin{array}{c}-0.1028 \\
(0.115)\end{array}$ \\
\hline $\begin{array}{l}\text { BA Co-Investment } \\
\text { with VC }\end{array}$ & & & & $\begin{array}{l}0.4643^{* * * * *} \\
(0.122)\end{array}$ & & $\begin{array}{l}0.4048^{* * * * *} \\
(0.126)\end{array}$ \\
\hline $\begin{array}{l}\text { Sequential Invest- } \\
\text { ment of VC after } \\
\text { BA }\end{array}$ & & & & $\begin{array}{l}0.5613^{\text {****** }} \\
(0.157)\end{array}$ & & $\begin{array}{l}0.5188^{* * * * *} \\
(0.161)\end{array}$ \\
\hline BA Staging & & & & & $\begin{array}{c}-0.1270 \\
(0.134)\end{array}$ & $\begin{array}{c}0.0525 \\
(0.136)\end{array}$ \\
\hline Constant & $\begin{array}{l}-9.2922^{* * * * * *} \\
(0.331)\end{array}$ & $\begin{array}{l}-9.0028^{* * 1 * * *} \\
(0.321)\end{array}$ & $\begin{array}{l}-9.2830^{* * * * *} \\
(0.347)\end{array}$ & $\begin{array}{l}-9.3619^{\text {****** }} \\
(0.341)\end{array}$ & $\begin{array}{l}-9.3310^{* * * * *} \\
(0.346)\end{array}$ & $\begin{array}{l}-9.0274^{\text {****** }} \\
(0.350)\end{array}$ \\
\hline $\begin{array}{l}\text { Company's Country } \\
\text { and Industry } \\
\text { Dummies }\end{array}$ & YES & YES & YES & YES & YES & YES \\
\hline $\begin{array}{l}\text { Year (at First } \\
\text { Round) Dummies }\end{array}$ & YES & YES & YES & YES & YES & YES \\
\hline$N$. of Companies & 1,933 & 1,933 & 1,857 & 1,933 & 1,933 & 1,857 \\
\hline Log-Likelihood & -596.37 & -581.51 & -584.04 & -586.45 & -595.95 & -562.41 \\
\hline Pseudo $R^{2}$ & 0.19 & 0.21 & 0.19 & 0.20 & 0.19 & 0.22 \\
\hline
\end{tabular}

Results from probit regressions on ultimate success. The dependent variable is the probability that the company had gone public or had been acquired by March 2014. The unit of analysis is the company. Robust standard errors are in brackets.

The asterisks, *,**, and **** indicate significance at the 10 percent, 5 percent, and 1 percent level, respectively. 


\begin{tabular}{|c|c|c|c|c|c|c|}
\hline & Model 1 & Model 2 & Model 3 & Model 4 & Model 5 & Model 6 \\
\hline $\begin{array}{l}\text { Average Number of } \\
\text { Investors per Round }\end{array}$ & $\begin{array}{l}0.9647^{\text {******* }} \\
(0.144)\end{array}$ & $\begin{array}{l}1.0630^{* * * * *} \\
(0.160)\end{array}$ & $\begin{array}{l}0.9164^{* * * * *} \\
(0.151)\end{array}$ & $\begin{array}{l}0.6677^{* * * * *} \\
(0.175)\end{array}$ & $\begin{array}{l}0.9617^{* * * * *} \\
(0.146)\end{array}$ & $\begin{array}{l}0.7461^{* * * *} \\
(0.194)\end{array}$ \\
\hline $\begin{array}{l}\text { Average Number of } \\
\text { Investors per Round } \\
\text { (squared) }\end{array}$ & $\begin{array}{l}-0.0679^{* * * * *} \\
(0.012)\end{array}$ & $\begin{array}{l}-0.0720^{* * * * *} \\
(0.012)\end{array}$ & $\begin{array}{l}-0.0648^{* * * * *} \\
(0.013)\end{array}$ & $\begin{array}{l}-0.0497^{\text {******* }} \\
(0.015)\end{array}$ & $\begin{array}{l}-0.0676^{* * * * *} \\
(0.012)\end{array}$ & $\begin{array}{l}-0.0522^{* * * * *} \\
(0.016)\end{array}$ \\
\hline $\begin{array}{l}\text { Total Number of } \\
\text { Financing Rounds }\end{array}$ & $\begin{array}{l}2.8391^{\text {****** }} \\
(0.230)\end{array}$ & $\begin{array}{l}2.9223^{\text {***** }} \\
(0.239)\end{array}$ & $\begin{array}{l}2.8457^{\text {**ak }} \\
(0.234)\end{array}$ & $\begin{array}{l}2.2790^{\text {***** }} \\
(0.230)\end{array}$ & $\begin{array}{l}2.8233^{* * * *} \\
(0.239)\end{array}$ & $\begin{array}{l}2.3195^{* * * * *} \\
(0.253)\end{array}$ \\
\hline $\begin{array}{l}\text { Total Number of } \\
\text { Financing Rounds } \\
\text { (squared) }\end{array}$ & $\begin{array}{l}-0.1914^{* * * * *} \\
(0.034)\end{array}$ & $\begin{array}{l}-0.1967^{\text {****** }} \\
(0.035)\end{array}$ & $\begin{array}{l}-0.1910^{\text {****** }} \\
(0.035)\end{array}$ & $\begin{array}{l}-0.1417^{* * * * *} \\
(0.028)\end{array}$ & $\begin{array}{l}-0.1905^{* * * *} \\
(0.034)\end{array}$ & $\begin{array}{l}-0.1435^{* * * * *} \\
(0.030)\end{array}$ \\
\hline $\begin{array}{l}\text { Company in the Seed } \\
\text { Stage at First Financ- } \\
\text { ing round }\end{array}$ & $\begin{array}{l}-1.3584^{* * * *} \\
(0.389)\end{array}$ & $\begin{array}{l}-1.3663^{* * * * *} \\
(0.389)\end{array}$ & $\begin{array}{l}-1.3054^{* * * * *} \\
(0.399)\end{array}$ & $\begin{array}{l}-1.1222 * * * * \\
(0.393)\end{array}$ & $\begin{array}{l}-1.3594^{* * * * *} \\
(0.389)\end{array}$ & $\begin{array}{l}-1.0955^{* * * * *} \\
(0.403)\end{array}$ \\
\hline $\begin{array}{l}\text { Company in the Early } \\
\text { Stage at First Financ- } \\
\text { ing Round }\end{array}$ & $\begin{array}{c}-0.7354^{*} \\
(0.394)\end{array}$ & $\begin{array}{c}-0.7653^{*} \\
(0.395)\end{array}$ & $\begin{array}{c}-0.6978^{*} \\
(0.402)\end{array}$ & $\begin{array}{c}-0.6561^{*} \\
(0.393)\end{array}$ & $\begin{array}{c}-0.7364^{*} \\
(0.394)\end{array}$ & $\begin{array}{c}-0.6690^{*} \\
(0.402)\end{array}$ \\
\hline $\begin{array}{l}\text { BA Experience in Early } \\
\text { Stage Investments }\end{array}$ & & $\begin{array}{r}0.0157 \\
(0.027)\end{array}$ & & & & $\begin{array}{r}0.0129 \\
(0.027)\end{array}$ \\
\hline $\begin{array}{l}\text { BA Experience in Later } \\
\text { Stage investments }\end{array}$ & & $\begin{array}{r}-0.0031 \\
(0.002)\end{array}$ & & & & $\begin{array}{c}-0.0034 \\
(0.002)\end{array}$ \\
\hline BA Co-Localization & & & $\begin{array}{r}0.3087 \\
(0.289)\end{array}$ & & & $\begin{array}{r}0.2545 \\
(0.291)\end{array}$ \\
\hline $\begin{array}{l}\text { BA Co-Investment with } \\
\text { VC }\end{array}$ & & & & $\begin{array}{l}1.3962^{* * * * *} \\
(0.327)\end{array}$ & & $\begin{array}{l}1.4139^{\text {****** }} \\
(0.343)\end{array}$ \\
\hline $\begin{array}{l}\text { Sequential Investment } \\
\text { of VC after BA }\end{array}$ & & & & $\begin{array}{l}1.8154^{* * * * *} \\
(0.368)\end{array}$ & & $\begin{array}{l}1.9101^{* * * * *} \\
(0.375)\end{array}$ \\
\hline BA Staging & & & & & $\begin{array}{l}0.0728 \\
(0.281)\end{array}$ & $\begin{array}{l}0.1926 \\
(0.288)\end{array}$ \\
\hline Constant & $\begin{array}{l}7.2175^{\text {******* }} \\
(2.272)\end{array}$ & $\begin{array}{l}6.9736^{\text {****** }} \\
(2.278)\end{array}$ & $\begin{array}{l}5.8710^{* * *} \\
(2.306)\end{array}$ & $\begin{array}{l}7.5612^{\text {***** }} \\
(2.180)\end{array}$ & $\begin{array}{l}7.2337^{\text {***:*** }} \\
(2.271)\end{array}$ & $\begin{array}{l}5.7282^{* * * * *} \\
(2.215)\end{array}$ \\
\hline $\begin{array}{l}\text { Company's Country } \\
\text { and Industry } \\
\text { Dummies }\end{array}$ & YES & YES & YES & YES & YES & YES \\
\hline $\begin{array}{l}\text { Year (at first round) } \\
\text { Dummies }\end{array}$ & YES & YES & YES & YES & YES & YES \\
\hline$N$. of companies & 1,933 & 1,933 & 1,857 & 1,933 & 1,933 & 1,857 \\
\hline$R^{2}$ & 0.23 & 0.23 & 0.23 & 0.24 & 0.23 & 0.25 \\
\hline
\end{tabular}

Results from OLS regressions on interim success. The dependent variable is the logarithm of the total amount of financing raised by the company by March 2014. The unit of analysis is the company. Robust standard errors are in brackets.

The asterisks, ${ }^{*}, * *$, and ${ }^{* * *}$ indicate significance at the 10 percent, 5 percent, and 1 percent level, respectively.

of interim performance the total amount of financing raised by the start-up, the probability of receiving more than one round of financing and the probability of receiving subsequent funding from a VC investor.
Amount of Financing Raised. We look at the total amount of financing received by performing OLS regressions. The unit of analysis is again the company and explanatory variables are as in the previous section (with the 


\begin{tabular}{|c|c|c|c|c|c|}
\hline & Model 1 & Model 2 & Model 3 & Model 4 & Model 5 \\
\hline Amount at First Round & $\begin{array}{r}0.0059 \\
(0.006)\end{array}$ & $\begin{array}{l}0.0062 \\
(0.006)\end{array}$ & $\begin{array}{l}0.0056 \\
(0.006)\end{array}$ & $\begin{array}{l}0.0051 \\
(0.006)\end{array}$ & $\begin{array}{l}0.0046 \\
(0.006)\end{array}$ \\
\hline $\begin{array}{l}\text { Number of Investors at } \\
\text { First Round }\end{array}$ & $\begin{array}{l}0.0980^{* * * * *} \\
(0.020)\end{array}$ & $\begin{array}{l}0.0878^{* * * *} \\
(0.022)\end{array}$ & $\begin{array}{l}0.1043^{* * * * *} \\
(0.021)\end{array}$ & $\begin{array}{l}0.0804^{* * * * * *} \\
(0.023)\end{array}$ & $\begin{array}{l}0.0760^{\text {***** }} \\
(0.025)\end{array}$ \\
\hline $\begin{array}{l}\text { Number of Investors at } \\
\text { First Round } \\
\text { (squared) }\end{array}$ & $\begin{array}{l}-0.0032^{* * * *} \\
(0.001)\end{array}$ & $\begin{array}{l}-0.0030 * * * * \\
(0.001)\end{array}$ & $\begin{array}{l}-0.0034^{* * * * *} \\
(0.001)\end{array}$ & $\begin{array}{l}-0.0026^{* * *} \\
(0.001)\end{array}$ & $\begin{array}{l}-0.0026^{* * *} \\
(0.001)\end{array}$ \\
\hline $\begin{array}{l}\text { Company in the Seed } \\
\text { Stage at First Round }\end{array}$ & $\begin{array}{l}0.6630^{* * * *} \\
(0.120)\end{array}$ & $\begin{array}{l}0.6749^{* * * * *} \\
(0.120)\end{array}$ & $\begin{array}{l}0.6551^{\text {***** }} \\
(0.123)\end{array}$ & $\begin{array}{l}0.6852^{* * * * *} \\
(0.121)\end{array}$ & $\begin{array}{l}0.6991^{* * * * *} \\
(0.124)\end{array}$ \\
\hline $\begin{array}{l}\text { Company in the Early } \\
\text { Stage at First Round }\end{array}$ & $\begin{array}{l}0.5369^{* * * * * *} \\
(0.122)\end{array}$ & $\begin{array}{l}0.5371^{* * * * * *} \\
(0.122)\end{array}$ & $\begin{array}{l}0.5293^{* * * *} \\
(0.125)\end{array}$ & $\begin{array}{l}0.5499^{* * * * *} \\
(0.122)\end{array}$ & $\begin{array}{l}0.5474^{* * * * * *} \\
(0.125)\end{array}$ \\
\hline $\begin{array}{l}\text { BA Experience in Early } \\
\text { Stage Investments at } \\
\text { First Round }\end{array}$ & & $\begin{array}{l}0.0196^{* * *} \\
(0.010)\end{array}$ & & & $\begin{array}{l}0.0217^{* * *} \\
(0.010)\end{array}$ \\
\hline $\begin{array}{l}\text { BA Experience in Later } \\
\text { Stage Investments at } \\
\text { First Round }\end{array}$ & & $\begin{array}{c}-0.0007 \\
(0.001)\end{array}$ & & & $\begin{array}{l}-0.0011^{*} \\
(0.001)\end{array}$ \\
\hline $\begin{array}{l}\text { BA Co-Localization at } \\
\text { First Round }\end{array}$ & & & $\begin{array}{c}-0.0738 \\
(0.082)\end{array}$ & & $\begin{array}{c}-0.0848 \\
(0.083)\end{array}$ \\
\hline $\begin{array}{l}\text { BA Co-Investment } \\
\text { with VC at First } \\
\text { Round }\end{array}$ & & & & $\begin{array}{l}0.1231 \\
(0.085)\end{array}$ & $\begin{array}{l}0.1648^{*} \\
(0.089)\end{array}$ \\
\hline Constant & $\begin{array}{l}-1.4878^{* * * * *} \\
(0.489)\end{array}$ & $\begin{array}{l}-1.5363^{* * * * *} \\
(0.480)\end{array}$ & $\begin{array}{l}-1.4454^{* * * * *} \\
(0.497)\end{array}$ & $\begin{array}{l}-1.5054^{* * * * *} \\
(0.489)\end{array}$ & $\begin{array}{l}-1.5121^{* * * * *} \\
(0.488)\end{array}$ \\
\hline $\begin{array}{l}\text { Company's Country } \\
\text { and Industry } \\
\text { Dummies }\end{array}$ & YES & YES & YES & YES & YES \\
\hline $\begin{array}{l}\text { Year (at first round) } \\
\text { Dummies }\end{array}$ & YES & YES & YES & YES & YES \\
\hline$N$. of (First) Rounds & 1,671 & 1,671 & 1,593 & 1,671 & 1,671 \\
\hline Log-Likelihood & $-1.04^{\circ}+03$ & $-1.03^{\circ}+03$ & -991.37 & $-1.04^{\circ}+03$ & -986.78 \\
\hline Pseudo $R^{2}$ & 0.06 & 0.07 & 0.06 & 0.07 & 0.07 \\
\hline
\end{tabular}

Results from probit regressions on interim success. The dependent variable is the probability that the company receives a follow on round of financing after receipt of the first financing round from a BA. The unit of analysis is the first round of financing in which at least a BA is present. Robust standard errors are in brackets.

The asterisks, *,**, and *** indicate significance at the 10 percent, 5 percent, and 1 percent level, respectively.

exception of the average amount per round). The dependent variable is the logarithm of the total amount of financing raised by the start-up by March 2014. Results are shown in Table 8.

Results clearly show that VC-backed start-ups raise more capital that non VC-backed start-ups. Both coefficients of BA co-investment with VC and sequential investment of $\mathrm{VC}$ after $\mathrm{BA}$ are indeed positive and strongly significant (at the 1 percent level) (Model 4 and Model 6), in line with $\mathrm{H} 3$. Conversely, other BA variables are not significant.

Follow on Financing. In Table 9, we examine which BA characteristics affect the probability of obtaining multiple rounds of financing. 


\begin{tabular}{|c|c|c|c|c|c|c|}
\hline & Model 1 & Model 2 & Model 3 & Model 4 & Model 5 & Model 6 \\
\hline Amount & $\begin{array}{c}-0.0016 \\
(0.008)\end{array}$ & $\begin{array}{r}-0.0081 \\
(0.008)\end{array}$ & $\begin{array}{l}0.0023 \\
(0.009)\end{array}$ & $\begin{array}{c}-0.0104 \\
(0.009)\end{array}$ & $\begin{array}{r}0.0007 \\
(0.008)\end{array}$ & $\begin{array}{c}-0.0095 \\
(0.010)\end{array}$ \\
\hline First Round & $\begin{array}{l}0.8869^{* * * * *} \\
(0.102)\end{array}$ & $\begin{array}{l}0.8663^{\text {***** }} \\
(0.101)\end{array}$ & $\begin{array}{l}0.6222^{* * * * *} \\
(0.107)\end{array}$ & $\begin{array}{l}0.7499 * * * * \\
(0.110)\end{array}$ & $\begin{array}{l}0.8815^{\text {****** }} \\
(0.101)\end{array}$ & $\begin{array}{l}0.5704^{* * * * * *} \\
(0.114)\end{array}$ \\
\hline Number of Investors & $\begin{array}{l}0.4112^{* * * * *} \\
(0.031)\end{array}$ & $\begin{array}{l}0.4175^{\text {***** }} \\
(0.034)\end{array}$ & $\begin{array}{l}0.2028^{* * * * * *} \\
(0.037)\end{array}$ & $\begin{array}{l}0.1788^{* * * * *} \\
(0.037)\end{array}$ & $\begin{array}{l}0.3754^{* * * * *} \\
(0.031)\end{array}$ & $\begin{array}{l}0.0378 \\
(0.046)\end{array}$ \\
\hline $\begin{array}{l}\text { Number of } \\
\text { Investors } \\
\text { (Squared) }\end{array}$ & $\begin{array}{l}-0.0121 \text { ***** } \\
(0.001)\end{array}$ & $\begin{array}{l}-0.0120^{* * * * *} \\
(0.001)\end{array}$ & $\begin{array}{l}-0.0044^{* * *} \\
(0.002)\end{array}$ & $\begin{array}{l}-0.0049^{* * * * *} \\
(0.002)\end{array}$ & $\begin{array}{l}-0.0105^{* * * * *} \\
(0.001)\end{array}$ & $\begin{array}{c}0.0012 \\
(0.002)\end{array}$ \\
\hline $\begin{array}{l}\text { Company in the Seed } \\
\text { Stage at } \\
\text { First Financing } \\
\text { Round }\end{array}$ & $\begin{array}{c}-0.0558 \\
(0.148)\end{array}$ & $\begin{array}{r}-0.0947 \\
(0.153)\end{array}$ & $\begin{array}{r}-0.0837 \\
(0.160)\end{array}$ & $\begin{array}{c}0.0861 \\
(0.168)\end{array}$ & $\begin{array}{r}-0.0809 \\
(0.149)\end{array}$ & $\begin{array}{l}0.1218 \\
(0.196)\end{array}$ \\
\hline $\begin{array}{l}\text { Company in the Early } \\
\text { Stage at } \\
\text { First Financing } \\
\text { Round }\end{array}$ & $\begin{array}{r}0.1837 \\
(0.142)\end{array}$ & $\begin{array}{c}0.1321 \\
(0.146)\end{array}$ & $\begin{array}{l}0.2818^{*} \\
(0.149)\end{array}$ & $\begin{array}{l}0.3082^{*} \\
(0.160)\end{array}$ & $\begin{array}{r}0.1687 \\
(0.142)\end{array}$ & $\begin{array}{l}0.4369^{* * *} \\
(0.190)\end{array}$ \\
\hline $\begin{array}{l}\text { BA Experience in } \\
\text { Early Stage } \\
\text { Investments }\end{array}$ & & $\begin{array}{l}0.0518^{\text {****** }} \\
(0.010)\end{array}$ & & & & $\begin{array}{l}0.0596^{\text {***** }} \\
(0.012)\end{array}$ \\
\hline $\begin{array}{l}\text { BA Experience in } \\
\text { Later Stage } \\
\text { Investments }\end{array}$ & & $\begin{array}{l}-0.0049^{* * * * * *} \\
(0.001)\end{array}$ & & & & $\begin{array}{l}-0.0047^{\text {***⿲丶丶㇒木火 }} \\
(0.001)\end{array}$ \\
\hline BA Co-Localization & & & $\begin{array}{l}1.5698^{* * * * * *} \\
(0.097)\end{array}$ & & & $\begin{array}{l}1.1944^{* * * * *} \\
(0.112)\end{array}$ \\
\hline $\begin{array}{l}\text { BA Co-Investment } \\
\text { with VC }\end{array}$ & & & & $\begin{array}{l}1.8788^{* * * *} \\
(0.126)\end{array}$ & & $\begin{array}{l}1.6060 \text { **** } \\
(0.153)\end{array}$ \\
\hline BA Staging & & & & & $\begin{array}{l}0.5704^{* * * * *} \\
(0.101)\end{array}$ & $\begin{array}{c}-0.0375 \\
(0.126)\end{array}$ \\
\hline Constant & $\begin{array}{c}-1.7408^{\text {***** }} \\
(0.592)\end{array}$ & $\begin{array}{c}-1.4455^{* *} \\
(0.612)\end{array}$ & $\begin{array}{c}-1.6688^{\text {****** }} \\
(0.565)\end{array}$ & $\begin{array}{c}-1.3514^{* * *} \\
(0.687)\end{array}$ & $\begin{array}{l}-1.6098^{* * * * *} \\
(0.602)\end{array}$ & $\begin{array}{c}-1.2383^{*} \\
(0.650)\end{array}$ \\
\hline $\begin{array}{l}\text { Company's Country } \\
\text { and Industry } \\
\text { Dummies }\end{array}$ & YES & YES & YES & YES & YES & YES \\
\hline $\begin{array}{l}\text { Year (at First Round) } \\
\text { Dummies }\end{array}$ & YES & YES & YES & YES & YES & YES \\
\hline$N$. of Rounds & 1,402 & 1,402 & 1,369 & 1,402 & 1,402 & 1,369 \\
\hline Log-Likelihood & -720.08 & -685.99 & -546.07 & -589.52 & -700.97 & -458.87 \\
\hline Pseudo $R^{2}$ & 0.25 & 0.29 & 0.42 & 0.39 & 0.27 & 0.51 \\
\hline
\end{tabular}

Results from probit regressions on interim success. The dependent variable is the probability that the company receives the subsequent round of financing from a VC after receipt of a financing round from a BA. The unit of analysis is the investment round of financing in which at least a $\mathrm{BA}$ is present. Robust standard errors are in brackets.

The asterisks, *,**, and *** indicate significance at the 10 percent, 5 percent, and 1 percent level, respectively.

Specifically, we run probit regressions where the dependent variable is the probability that the start-up receives a follow-on round of financing after receipt of the first financing round from BAs. The unit of analysis is therefore the first round of financing in which at least a $\mathrm{BA}$ is present. Explanatory variables are the BA experience in early and later stage 
investments (calculated as the maximum number of prior investments of BAs involved in the first financing round in the early and later stage, respectively), the $\mathrm{BA}$ co-localization (i.e., a dummy that equals 1 if at least a BA involved in the first round is in the same State or country of the focal company) and the BA co-investment with a VC in the first financing round. We control for the amount of capital raised, the number of investors (and its squared term) and the company stage (seed or early) in the first financing round. We also include company's industry and country dummies and dummies related to the year in which the company received the first financing round.

Table 9 shows that BA experience in early stage investments is positive and statistically significant (at the 5 percent level) in both Model 2 and Model 5. This evidence is consistent with the view that receipt of a first financing round from BAs with an extensive experience in the provision of early stage finance provides a valuable signal to entrant investors. This result is in line with H1a even though here we do not distinguish whether these entrant investors are BAs or VCs (please see the next section in which we provide evidence that further supports H1a). Conversely, in Model 5 (but not in Model 2) we find that BA experience in later stage investments is negative and significant at the 10 percent level. We also find a weak evidence on the role of BA co-investment with VC on the probability to attract follow on rounds (Model 5).

Follow-on Financing from VC. To shed light on the signaling role of BA financing towards $\mathrm{VC}$, in this section we display results on probit models on the ability of the start-up to raise follow-on financing from VCs. The unit of analysis is the investment round. We restrict the sample only to investment rounds in which a BA is present (but not necessarily the first round of financing). The dependent variable is the probability that the start-up receives the subsequent round of financing from a VC. ${ }^{10}$ Again, we consider the BA experience in early and later stage investments, the BA co-localization, and the BA co-investment with VC. With respect to the estimates show in Table 9, which refer only to the first financing round, here we consider also the BA staging variable, which equals 1 if the same
BA provided multiple rounds to the focal company. We control for the amount of capital raised and the number of investors (and its squared term) in the round and the company stage (seed or early) in the first financing round. Furthermore, we also include a dummy variable that equals 1 in the first round of financing. Finally, we include company's industry and country dummies and dummies related to the year in which the company received the first financing round.

Model 2 and Model 6 in Table 10 clearly show that while the coefficient of BA experience in early stage investments is positive and statistically significant (at the 1 percent level), BA later stage experience yields to the opposite effect. These results thus confirm $\mathrm{H1a}$ and $\mathrm{H} 1 \mathrm{~b}$. BA experience in early stage investments is positively associated with the attraction of $\mathrm{VC}$ financing ( $\mathrm{H} 1 \mathrm{a})$, while the $\mathrm{BA}$ experience in later stage investments reduces the chances of obtaining VC (H1b). As to BA investment behavior, we find that the co-localization of BAs and investees is positively associated with additional VC financing (Model 3 and Model 6), in line with $\mathrm{H} 2$. Finally, BA co-investment with VC is positively associated with additional VC financing (Model 4 and Model 6), in line with H3.

\section{Conclusion}

Although previous studies suggest that BA financing dominates VC financing globally (Fenn and Liang 1998; Hellmann and Thiele 2015; OECD 2011; Wiltbank et al. 2009) and that BAs are as important for high potential start-ups as VCs (e.g., Freear, Sohl, and Wetzel 1995; Landström 1993; Mason and Harrison 1994; Shane 2012), limited attention has been paid to such field of the entrepreneurial finance literature. Due to the paucity of data on BAs, most of the extant studies are mainly descriptive or rely on small scale surveys. In addition, the few empirical assessments have generally examined the post-investment performance of angelbacked firms compared to non-angel backed ones, without focusing on the attitudes and traits of BAs. This paper represents a first attempt to fill this gap. Using a large sample of 1,933 BA-backed high-tech start-ups extracted from Crunchbase, we have provided more finegrained insights than hitherto about how BAs

\footnotetext{
${ }^{10}$ It is worth pointing out that the dependent variable is defined only if the focal company receives a subsequent round of financing.
} 
capabilities and investment behavior affect the performance of financed start-ups. Specifically, we have linked the BA's capabilities (proxied by their investment experience in both early and later stage rounds) and the BA's investment behavior (i.e., established links with VCs, colocalization of BA investors and funded startups in the same area, and monitoring via staged capital injections) to the interim and ultimate start-up's success.

Results from the econometric estimates confirm most of our hypotheses. The experience of BAs in early stage investment rounds is positively associated with a better interim performance, in terms of follow-on rounds of financing and sequential capital injections from a VC (H1a), while later stage experience reduces the need for new VCs to invest in the start-up (H1b). The co-localization of BA investors and investees in the same area positively affects the probability to attract VC financing (H2). Combining BA and VC financing leads to greater amounts raised by the company and an increased probability to obtain additional VC financing (H3). Furthermore, it is positively related to the ultimate start-up's success (H4). Finally, we do not find support for the hypothesis $\mathrm{H} 5$ since we do not detect a significant evidence on the role of $\mathrm{BA}$ staging on ultimate performance.

The study has some limitations that suggest avenues for future research. First, our measures of interim and ultimate performance could be enriched in the presence of financial accounting data for invested start-ups and internal rates of return (IRR) for investors. Future research should strive to obtain accounting information to evaluate start-ups' financial performance, in order to provide more refined measures of success. In addition, scholarly works might usefully look at the impact of BA financing on further measures of entrepreneurial activity (e.g., innovation and $R \& D$ expenditures, labor productivity, total factor productivity and international exposure).

Second, we have proxied the capabilities of BAs with their previous investment experience, while a more in-depth analysis should also consider further elements that might eventually explain differential impacts on invested firms, such as the BAs reputation, previous entrepreneurial experience (serial versus virgin angels), competences and education. Future research could extend the exploration of these issues by assembling unique data sets on BAs' human capital characteristics and competencies.

Third, our findings suggest that a BA with a renowned experience in later stage rounds increases the likelihood that the venture undergoes a successful exit, while it reduces the need for new VCs to invest in the start-up. Higher ultimate performances are also envisaged when VCs and BAs co-invest and when a sequential investment by a VC occurs. A fruitful direction for future research could be to explore what is best for a start-up and to investigate further the dynamics of the interaction between BAs and VCs. Are performances enhanced when the start-up is backed by a BA alone, with the necessary experience to coach the start-up to later stages of development? Or rather when the BA leaves the floor to a VC?

Finally, despite a non-negligible proportion of investments in our sample involves European start-ups, it has to be acknowledge that our data are mostly focused on start-ups located in North America (around 70 percent), especially in the United States. One may therefore wonder whether our results can be actually generalized on a global perspective. Of course, we hope that the coverage of BA activity by Crunchbase or other commercially available databases will be improved in the future.

Our findings offer several practical implications for both entrepreneurs who are looking for financing and investors (BAs and VCs). On the one hand, entrepreneurs should carefully consider the BA to be associated with, in order to gain the most of advantage from his/her competences and experience. In particular, entrepreneurs might face a trade-off when evaluating the investment proposal by a BA. Being backed by BAs with a proved investment experience in later stages of development would assure the start-up a higher probability of ultimate success, without incurring into the risk of ownership dilution and tight control and monitoring measures that the VC intervention would require. However, this would imply more difficulties for the start-up to switch to another BA or to a VC over the years, unless the BA investor decides to prematurely leave the company. Conversely, an initial investment by a BA with experience in early stage rounds could provide a certification function towards other private sources of capital that might otherwise have been out of reach for the start-up. Entrepreneurs will see substantive benefits down the road in terms of IPO likelihood if VCs commit time and resources to the venture. 
On the other hand, the findings also have implications on both BAs and VCs that are looking for syndicate partners and new deals in which to invest. BAs should favor co-investment arrangements with VCs because of the substantial benefits that may derive, in terms of investment selection process, through improved screening, due diligence and decision-making, and postinvestment performance, through better monitoring and value added services provided. In turn, a VC will join a syndicate with BAs in order to exploit their specific knowledge and complementary skills. An examination of the performance of syndicated deals between BAs and VCs, relative to nonsyndicated deals, represents an interesting aspect for future research.

Finally, our results have clear implications for policy makers. A deeper understanding of the conditions under which angel financing facilitates the alleviation of the equity gap is crucial for those policy makers who intend enhancing financing offers to entrepreneurs. The increasing difficulties that high-tech start-ups face in raising external finance call for new challenges for public bodies, which have to rethink their approach to the regulation of financial institutions and financial markets and to create the enabling conditions to mobilize risk capital. In this regard, policy makers should find adequate routes to help local businesses develop to the point that they are attractive to BAs. In particular, a clearer understanding of the benefits that arise from complementarity relationships between VCs and BAs will enable policy makers to better design public initiatives aimed at increasing the supply of early stage risk capital. If the early stage capital markets are to operate more efficiently and the available capital is to be more effectively routed to high growth potential companies, VCs need to develop closer relationships with BAs, either by choosing BAs as syndication partners or by entering deals first financed by BAs. In this sense, the arena for public intervention is large, since these complementarities are more likely to develop on a local/regional basis.

\section{References}

Admati, A. R., and P. Pfleiderer (1994).

"Robust Financial Contracting and the Role of Venture Capitalists," Journal of Finance 49(2), 371-403.

Amis, D., and H. Stevenson (2001). Winning Angels: The Seven Fundamentals of Early
Stage Investing. London, UK: Pearson Education.

Angel Capital Education Foundation (2009). "Important Things for Entrepreneurs to Know about Angel Investors." Available at: http://www.angelcapitalassociation.org/data/ Documents/Press\%20Center/What\%20Ents\% 20Should\%20Know\%20About\%20Angels\% 202009.pdf (accessed July 1, 2015).

Bammens, Y., and V. Collewaert (2014). "Trust Between Entrepreneurs and Angel Investors: Exploring Positive and Negative Implications for Venture Performance Assessments," Journal of Management 40(7), 1980-2008.

Bergemann, D., and U. Hege (1998). "Venture Capital Financing, Moral Hazard, and Learning," Journal of Banking and Finance 22(6), 703-735.

Bonnet, C., and P. Wirtz (2012)."Raising Capital for Rapid Growth in Young Technology Ventures: When Business Angels and Venture Capitalists Coinvest," Venture Capital 14(2-3), 91-110.

Bruton, G., I. Filatotchev, S. Chahine, and M. Wright (2010). "Governance, Ownership Structure, and Performance of IPO Firms: The Impact of Different Types of Private Equity Investors and Institutional Environments," Strategic Management Journal 31(5), 491-509.

Carpenter, R., and B. Petersen (2002). "Capital Market Imperfections, High-Tech Investment and New Equity Financing," Economic Journal 112(477), F54-F72.

Collewaert, V., and S. Manigart (2016). "Valuation of Angel-Backed Companies: The Role of Investor Human Capital," Journal of Small Business Management 54(1), 356-372.

Coveney, P., and K. Moore (1998). Business Angels: Securing Start-up Finance. Chichester, UK: John Wiley \& Sons.

Chahine, S., I. Filatotchev, and M. Wright (2007). "Venture Capitalists, Business Angels, and Performance of Entrepreneurial IPOs in the UK and France," Journal of Business Finance \& Accounting 34(3-4), 505-528.

Chemmanur, T. J., and Z. Chen (2014). "Venture Capitalists versus Angels: The Dynamics of Private Firm Financing Contracts," Review of Corporate Finance Studies 3(1-2), 39-86.

Cumming, D., and N. Dai (2010). "Local Bias in Venture Capital Investments," Journal of Empirical Finance 17(3), 362-380. 
(2013). "Why Do Entrepreneurs Switch Lead Venture Capitalists?" Entrepreneurship: Theory and Practice 37(5), 999-1017.

CVR (2003). The Angel Investor Market in 2002: Investment Activity and Growth Prospects. New Hampshire: Center for Venture Research. Available at: http://paulcollege. unh.edu/files/FY_2002_Press_Release.pdf (accessed November 25, 2014).

Dai, N. (2011). Monitoring via Staging: Evidence from Private Investments in Public Equity," Journal of Banking \& Finance 35(12), 3417-3431.

De Clercq, D., V. Fried, O. Lehtonen, and H. Sapienza (2006). “An Entrepreneur's Guide to the Venture Capital Galaxy" Academy of Management Perspectives 20(3), 90-112.

Ehrlich, S., A. De Noble, T. Moore, and R. Weaver (1994). "After the Cash Arrives: A Comparative Study of Venture Capital and Private Investor Involvement in Entrepreneurial Firms," Journal of Business Venturing 9(1), 67-82.

Fairchild, R. (2011). “An Entrepreneur's Choice of Venture Capitalist or Angel-Financing: A Behavioral Game-Theoretic Approach," Journal of Business Venturing 26(3), 359-374.

Fenn, G. W., and N. Liang (1998). "New Resources and New Ideas: Private Equity for Small Business," Journal of Banking \& Finance 22(6), 1077-1094.

Freear, J., and W. E. Wetzel (1990). "Who Bankrolls High-Tech Entrepreneurs?" Journal of Business Venturing 5(2), 77-89.

Freear, J., J. E. Sohl, and W. Wetzel (1995). "Angels: Personal Investors in the Venture Capital Market," Entrepreneurship and Regional Development 7(1), 85-94.

—_ - (2002). "Angles on Angels: Financing Technology Based Ventures-A Historical Perspective," Venture Capital 4(4), 275-287.

Gompers, P., and J. Lerner (2001). "The Venture Capital Revolution," Journal of Economic Perspectives 15(2), 145-168.

Goldfarb, B., G. Hoberg, D. Kirsch, and A. Triantis (2013). "Are Angels Different? An Analysis of Early Venture Financing," Robert H. Smith School Research Paper No. RHS 06-072. Available at: http://ssrn.com/ abstract $=1024186$ (accessed November 25, 2014).

Hall, B. H. (2002). "The Financing of Research and Development," Oxford Review of Economic Policy 18(1), 35-51.
Harrison, R. T. and C. M. Mason (2000). "Venture Capital Market Complementarities: The Links Between Business Angels and Venture Capital Funds in the United Kingdom," Venture Capital 2(3), 223-242.

Hellmann, T., and V. Thiele (2015). "Friends or Foes? The Interrelationship between Angel and Venture Capital Markets," Journal of Financial Economics 115(3), 639-653.

Hellmann, T., P. Schure, and D. Vo (2013). "Angels and Venture Capitalists: Complements or Substitutes?" Working paper. Available at: http://strategy.sauder.ubc.ca/hell mann/pdfs/HellmannSchureVo15-11-09.pdf (accessed November 25, 2014).

Hochberg, Y., A. Ljungqvist, and Y. Lu (2007). "Whom You Know Matters: Venture Capital Networks and Investment Performance," The Journal of Finance 62(1), 251-301

Johnson, W. C., and J. Sohl (2012). "Angels and Venture Capitalists in the Initial Public Offering Market," Venture Capital 14(1), 27-42.

Kerr, W. R., J. Lerner, and A. Schoar (2014). "The Consequences of Entrepreneurial Finance: Evidence from Angel Financings," Review of Financial Studies 27(1), 20-55.

Landström, H. (1993). "Informal Risk Capital in Sweden and Some International Comparisons," Journal of Business Venturing 8(6), 525-540

Lerner, J. (1994). "Venture Capitalists and the Decision to Go Public," Journal of Financial Economics 35(3), 293-316.

Lindsay, N. (2004). "Do Business Angels have an Entrepreneurial Orientation?" Venture Capital 6(2-3), 197-210.

Madill, J. J., G. H. Haines, and A. L. Riding (2005). "The Role of Angels in Technology SMEs: A Link to Venture Capital," Venture Capital 7(2), 107-129.

Mason, C. M. (2006). "Informal Sources of Venture Finance," in The Life Cycle of Entrepreneurial Ventures. Ed. S. Parker, New York: Springer, 259-299.

Mason, C. M., and R. T. Harrison (1994). "The Role of Informal and Formal Sources of Venture Capital in the Financing of Technology-Based SMEs in the United Kingdom," in New Technology-Based Firms in the 1990s. Ed. R. Oakey, London: Paul Chapman Publishing, 104-124.

Morrissette, S. (2007). "A Profile of Angel Investors," The Journal of Private Equity 10(3), 52-66. 
Neher, D. (1999). "Staging: An Agency Perspective," Review of Economic Studies 66(2), 255-274.

OECD (2011). Financing High-Growth Firms: The Role of Angel Investors. OECD Publishing. Available at: http://dx.doi.org/10.1787/ 9789264118782-en (accessed November 25, 2014).

Phalippou, L. and O. Gottschalg (2009). "The Performance of Private Equity Funds," Review of Financial Studies 22 (4), 1747-1776.

Prowse, S. (1998). "Angel Investors and the Market for Angel Investments," Journal of Banking \& Finance 22(6-8), 785-792.

Sahlman, W. (1988). "Aspects of Financial Contracting in Venture Capital," Journal of Applied Corporate Finance 1(2), 23-36.

Shane, S. (2012). "The Importance of Angel Investing in Financing the Growth of Entrepreneurial Ventures," Quarterly Journal of Finance 2(2), 1-42.

Sohl, J. (1999). "The Early-Stage Equity Market in the USA," Venture Capital 1(2), 101-121. (2005). The Angel Investor Market in 2004. Durham, NH: University of New Hampshire, Centre for Venture Research. http://www.unh.edu/news/docs/cvr2004.pdf (accessed November 25, 2014).
Sørensen, M. (2007). "How Smart Is Smart Money? A Two-Sided Matching Model of Venture Capital," Journal of Finance 62(6), 2725-2762.

Tian, X. (2011). "The Causes and Consequences of Venture Capital Stage Financing," Journal of Financial Economics 101(1), 132-159.

Van Osnabrugge, M. (2000). "A Comparison of Business Angel and Venture Capitalist Investment Procedures: An Agency Theory Based Analysis," Venture Capital 2(2), 91-110.

Wang, S., and H. Zhou (2004). "Staged Financing in Venture Capital: Moral Hazard and Risks," Journal of Corporate Finance 10(1), 131-155.

Werth, J. C. and P. Boeert (2013). "Co-investment Networks of Business Angels and the Performance of Their Start-up Investments," International Journal of Entrepreneurial Venturing 5(3), 240-256.

Wiltbank, R. (2005). "Investment Practices and Outcomes of Informal Venture Investors," Venture Capital 7(4), 343-357.

Wiltbank, R., S. Read, N. Dew, and S. D. Sarasvathy (2009). "Prediction and Control under Uncertainty: Outcomes in Angel Investing," Journal of Business Venturing 24(2), 116-133. 